\section{Assessment of the microbiolog- ical quality of popular food items on sale in secondary school canteens of Mauritius}

\author{
Dayawatee Goburdhun, ${ }^{1}$ \\ Mahima D. Beeharry, ${ }^{1}$ Keshnee Reega, ${ }^{1}$ \\ Arvind Ruggoo, ${ }^{2}$ Hudaa Neetoo ${ }^{1}$ \\ ${ }^{1}$ Department of Agricultural and Food \\ Science, and ${ }^{2}$ Department of \\ Agricultural Production Systems, \\ Faculty of Agriculture, University of \\ Mauritius, Réduit, Mauritius
}

\begin{abstract}
This study was carried out to assess the microbiological status of three hot meals served in eight selected school canteens of Mauritius, with two schools randomly selected from each of the four school zones of the island. Three individual samples of farata, panini, or fried noodles were collected at each school during two independent visits. The three individual samples of each food type collected during each visit were then pooled before being subjected to microbiological analyses. A total of 48 composite samples were analyzed. The parameters tested were Total Viable Count (TVC), Escherichia coli, Salmonella spp., Clostridium perfringens, Staphylococcus aureus, and Listeria spp. The microbiological analyses revealed that paninis were deemed as generally acceptable with TVC falling in the range of 3.0-5.7 Log CFU/g and undetectable levels of $S$. aureus and $E$. coli. In contrast, fried noodles and faratas harboured a moderately high level of TVC (4.4-6.7 Log CFU/g) and objectionably high levels S. aureus (3.1 to 5.0 Log CFU/g) and $E$. coli (3.1-5.1 Log CFU/g) for seven out of the eight schools.
\end{abstract}

\section{Introduction}

Food is an important basic necessity; it is a critical contributor to the physical wellbeing and its procurement, preparation, and consumption are vital for sustenance of life. However, infectious diseases that spread through food vehicles are common and can result in appreciable morbidity and occasionally in death (Scharff et al., 2009; Tomohide, 2010) According to the Centers for Disease Control and Prevention (CDC), bacterial agents such as Salmonella spp., Escherichia coli, Campylobacter spp., Shigella spp., Listeria spp., and Vibrio spp. have been implicated in foodborne diseases (CDC, 2009). Ready-to-eat foods (RTE) have been found to be highly contaminated with various pathogens such as $E$. coli and S. aureus (Edema and Omemu, 2004). These bacteria can survive on hands and surfaces and eventually become transferred to food (Lues and Van Tonder, 2007). Although foodborne disease is a matter of concern for the general public, it is a particularly high concern for school children for whom foodborne infections can be life threatening (Hayes et al., 2003). Indeed, school children are one of the most susceptible population groups. It is therefore not surprising that foodborne illnesses are more concentrated in schools and institutions rather than in the general community (Meftahuddin, 2002; Soon et al., 2011). From 1990s until today, foodborne disease outbreaks have predominantly occurred in schools (62\%) and academic institutions $(17 \%)$ and a much smaller proportion (8\%) in community gatherings in Malaysia (Soon et al., 2011). An in-depth analysis of food poisoning cases in Mauritius revealed that the distribution of food poisoning reported to the Ministry of Health and Quality of Life (MoHQL) was skewed towards individuals in the lower age group of 10-19 (28.2\%) and 20-29 (22.4\%) (MoHQL, 2014). Many students attending secondary schools regularly purchase RTE hot foods at school canteens. In addition to being nutritious, these RTE hot foods also need to be safe and hygienic. The contamination of RTE foods, even with low levels of S. aureus, Bacillus cereus, or Clostridium perfringens, can compromise the health of the general population due to pre-formed heat-stable enterotoxins in the food. Low levels may be due to natural contamination of raw materials used in the preparation of those foods, but usually their presence suggests faults in the production or subsequent handling of food, which could lead to an unacceptable increase in risk. Enumeration and/or detection of foodborne pathogenic agents at any level is of concern and should thus be investigated with an urgency of response proportionate to the level of contamination and risk to consumers. The objectives of this study were therefore to determine the microbiological and hygienic status of three popular hot meals, namely farata (Indian flatbread), panini, and fried noodles served in secondary school canteens of Mauritius.

\section{Materials and Methods}

A total of eight schools were approached during two independent visits
Correspondence: Hudaa Neetoo, Department of Agricultural and Food Sciences, Faculty of Agriculture, University of Mauritius, Réduit, Moka 80837, Mauritius.

Tel.: +230.403.7885 - Fax: +230.465.5743.

E-mail: s.neetoo@uom.ac.mu

Key words: school canteen, ready-to-eat foods, bacteria, food borne disease, pathogens

Acknowledgements: the authors would like to thank the Ministry of Education and Human Resources, Tertiary Education and Scientific Research for giving us permission to carry out this research in the secondary schools. Thanks are also extended to Ms. Sandy Tang Sik Fon and Mr. Irfaan Heetun for data collection.

Contributions: $\mathrm{MDB}, \mathrm{HN}$, data collection and analysis; DG, MDB, AR, HN, KR manuscript write-up.

Conflict of interest: the authors declare no potential conflict of interest.

Funding: University of Mauritius.

Received for publication: 2 February 2018.

Revision received: 20 April 2018.

Accepted for publication: 7 May 2018.

This work is licensed under a Creative Commons Attribution-NonCommercial 4.0 International License (CC BY-NC 4.0).

(C) Copyright D. Goburdhun et al., 2019

Licensee PAGEPress, Italy

Italian Journal of Food Safety 2019; 8:7326

doi:10.4081/ijfs.2019.7326

for sample collection, with two schools randomly selected from each of the four school zones of Mauritius. Three individual samples of each of farata, panini, and fried noodles were collected during each visit at each school and were aseptically transported to the laboratory in a chilled cooler bag for analysis. The three individual samples of each food type originating from the same batch of preparation were then pooled to form one composite sample. A total of 48 composite samples were analyzed, with 16 composites for each food type. $25 \mathrm{~g}$ of each pooled sample was aseptically weighed and transferred to a stomacher bag to which $225 \mathrm{~mL}$ of sterile $0.1 \%$ buffered peptone water was added. The sample was blended for two minutes at 230 RPM in a stomacher to produce a homogeneous sample, which was then diluted in $0.1 \%$ sterile Buffered Peptone water to achieve a 10 -fold dilution series. Enumerations of TVC, S. aureus, C. perfringens, Listeria monocytogenes, and $E$. coli were done by plating appropriate dilutions on Plate Count agar (ISO 4833:2003), Baird Parker agar (ISO 68881:1999), Iron Sulphite agar (ISO 
15213:2003), PALCAM agar (Pinto et al., 2001) and Eosin Methylene Blue agar (Bello et al., 2011) respectively. Detection of Salmonella was carried out by enrichment of samples followed by streaking on Xylose Lysine Deoxycholate agar (ISO 6579:2002). The inoculated plates were then incubated at $35^{\circ} \mathrm{C}$ for 48 hours. Where appropriate, data were analyzed using Minitab $^{\circledR}$ Release 17. A single factor analysis of variance (ANOVA) and Tukey's oneway multiple comparisons were conducted to determine differences in the population means of the different bacterial species. Significant differences were considered at the $95 \%$ confidence level $(\mathrm{P}<0.05)$.

\section{Results and Discussion}

Table 1 compares the microbiological profile of different RTE food items (farata, panini, and fried noodles) sold in secondary school canteens. Mean population density of mesophilic aerobic bacteria, E. coli and $S$. aureus ranged from 4.7-6.7, 3.4-5.1, <2$5.0 \mathrm{Log}$ CFU/g for faratas, 3.0-5.7, $<2,<2$ $\mathrm{Log}$ CFU/g for panini and 4.4-6.7, $<2-4.1$, $<2-4.2 \mathrm{Log}$ CFU/g for noodles respectively, highlighting their variable microbiological quality. No significant difference $(\mathrm{P}>0.05)$ was observed in the TVC load of faratas except for faratas from one school canteen (Canteen E), which had a significantly lower TVC carriage of $4.7 \mathrm{Log} \mathrm{CFU} / \mathrm{g}$. With regard to panini, the quality of the product sold at school D was inferior to that of the 7 other schools due to a significantly higher TVC carriage $(\mathrm{P}<0.05)$ of $6.7 \mathrm{Log}$ $\mathrm{CFU} / \mathrm{g}$. No significant difference $(\mathrm{P}>0.05)$ was observed among the different schools as far as the general microbiological quality of noodles is concerned. ICMSF (1996) states that RTE foods with TVC falling in the range of $0-10^{3} \mathrm{CFU} / \mathrm{g}(0-3 \mathrm{Log} \mathrm{CFU} / \mathrm{g})$, $10^{4}-10^{5} \mathrm{CFU} / \mathrm{g}(4-5 \mathrm{Log} \mathrm{CFU} / \mathrm{g})$ and $>10^{6}$
$\mathrm{CFU} / \mathrm{g}$ (or $\geq 6 \mathrm{Log} \mathrm{CFU} / \mathrm{g}$ ) are considered acceptable, marginally acceptable (tolerable), or unacceptable respectively. On the other hand, the Mauritius Food Regulations (MoHQL, 1999) and New Zealand Food Regulations (1984) are more stringent stating that RTE foods with TVC exceeding $10^{5}$ $\mathrm{CFU} / \mathrm{g}$ are of objectionable quality and therefore unfit for consumption. Based on the microbiological standards used, faratas and fried noodles sold at several canteens were deemed unacceptable for sale.

A recent study (Fon et al., 2016) showed that noodles sold in retail outlets of Mauritius harboured relatively high levels of mesophilic aerobes as well as spoilage and pathogenic bacteria making them fairly perishable. It is therefore not surprising that noodles have been recurrently incriminated in food poisoning incidents in Mauritius with an incidence rate of $17.2 \%$ (Fon et al., 2016). Furthermore, it was reported that $19 \%$ of all food poisoning incidents occurred in educational institutions, implicating foods such as noodles and faratas (Hotee, 2011). Fried noodles are notorious for being prepared in advance, stored uncovered at room temperature for long hours coupled with poor personal hygiene (Ghaffar et al., 2009). Faratas are manually handled extensively with its curry filling cooked in large batches. Factors such as the slow cooling of the curry, subsequent exposure to contaminants via food handlers, utensils, the environment, and the rich medium contribute to the increased microbial loads of the samples (Abdussalam and Käferstein, 1993). The moderate to high TVC counts of the different food items can also be explained by the fact that they comprise of sliced ingredients such as sliced chicken and tomatoes in panini and sliced green beans and carrots in fried noodles. Cross-contamination could likely occur via equipment (i.e. slicer, knives and/or chopping boards) contributing to the high population of mesophilic aerobes. A stringent hygienic practice during manipulation of ingredients is thus necessary during the preparation of these products (Kotzekidou, 2013). Although panini purchased from most schools harboured TVC in the range of 3-4 Log CFU/g, one school had a significantly $(\mathrm{P}<0.05)$ higher TVC count of 5.7 Log CFU/g. High aerobic counts alone do not make a food unsafe but do indicate poor handling, storage, or inadequate general hygiene (Gillespie et al., 2000). The occasionally poor microbiological status of panini noted in this study could partly be attributed to poor temperature control. In fact, Kotzekidou (2013) noted a fairly high level of mesophilic aerobes exceeding 8 Log CFU/g in sandwiches stored at ambient temperatures. Similarly, considerably higher aerobic plate counts $\left(10^{9} \mathrm{CFU} / \mathrm{g}\right)$ were observed for filled baguettes from retail delicatessens in South Africa sold at room temperature (Christison et al., 2008). For this reason, it is recommended that sandwiches be retailed at $5^{\circ} \mathrm{C}$ and never higher than $8^{\circ} \mathrm{C}$ (BSA, 2015). Better temperature control needs to be enforced in retail points at schools since these chicken panini are typically sold at ambient temperatures. Moreover, these are left exposed to air and are not properly covered, thereby encouraging the growth of mesophilic aerobic bacteria to unacceptable levels.

$S$. aureus counts ranged from $<2-5.0$, $<2$, and $<2-4.2 \mathrm{Log}$ CFU/g for faratas, pani$\mathrm{ni}$, and fried noodles respectively. $S$. aureus was recovered from faratas from four schools and fried noodles from two schools at a level falling in the range of 4-5 Log $\mathrm{CFU} / \mathrm{g}$. According to the Mauritius Food Regulations (MoHQL, 1999), the maximum tolerable level of $S$. aureus in food is $2 \mathrm{Log}$ $\mathrm{CFU} / \mathrm{g}$ thus, rendering faratas and fried noodles unfit for consumption on many instances. Soriano et al. (2002) recovered $S$. aureus from $11.1 \%$ of university cafeteria meals at levels ranging from 2-4.7 Log CFU/g (Soriano et al., 2002). Similarly,

Table 1. Comparative bacterial population density of three main course meals from eight schools.

\begin{tabular}{|c|c|c|c|c|c|c|c|c|c|}
\hline \multirow[t]{2}{*}{ School code } & \multicolumn{3}{|c|}{ Farata } & \multicolumn{3}{|c|}{ Panini } & \multicolumn{3}{|c|}{ Fried Noodles } \\
\hline & TVC & E. coli & S. aureus & TVC & E. coli & S. aureus & TVC & E. coli & S. aureus \\
\hline A & $6.5 \pm 0.6^{\mathrm{ab}}$ & $4.9 \pm 0.5^{\mathrm{ab}}$ & $3.3 \pm 0.5^{\mathrm{ab}}$ & $3.8 \pm 0.6^{\mathrm{b}}$ & $<2.0 \pm 0.0^{\mathrm{b}}$ & $<2.0 \pm 0.0^{\mathrm{a}}$ & $5.2 \pm 0.5^{\mathrm{a}}$ & $3.5 \pm 0.4^{\mathrm{a}}$ & $<2.0 \pm 0.0^{\mathrm{b}}$ \\
\hline B & $6.7 \pm 0.5^{\mathrm{a}}$ & $3.4 \pm 0.5^{b}$ & $4.1 \pm 0.6^{\mathrm{ab}}$ & $3.7 \pm 0.9^{\mathrm{b}}$ & $<2.0 \pm 0.0^{\mathrm{b}}$ & $<2.0 \pm 0.0^{\mathrm{a}}$ & $6.3 \pm 0.7^{\mathrm{a}}$ & $3.1 \pm 0.3^{\mathrm{a}}$ & $4.1 \pm 0.7^{\mathrm{a}}$ \\
\hline $\mathrm{C}$ & $6.7 \pm 0.5^{\mathrm{a}}$ & $3.7 \pm 0.4^{\mathrm{ab}}$ & $<2.0 \pm 0.0^{\mathrm{b}}$ & $3.8 \pm 0.3^{\mathrm{b}}$ & $<2.0 \pm 0.0^{b}$ & $<2.0 \pm 0.0^{\mathrm{a}}$ & $6.7 \pm 0.4^{\mathrm{a}}$ & $<2.0 \pm 0.0^{\mathrm{ab}}$ & $3.6 \pm 0.3^{\mathrm{a}}$ \\
\hline D & $6.7 \pm 0.5^{\mathrm{a}}$ & $3.4 \pm 0.6^{\mathrm{ab}}$ & $3.6 \pm 0.8^{\mathrm{ab}}$ & $5.7 \pm 0.7^{\text {a }}$ & $3.9 \pm 0.3^{\mathrm{a}}$ & $<2.0 \pm 0.0^{\mathrm{a}}$ & $5.1 \pm 0.4^{\mathrm{a}}$ & $3.6 \pm 0.8^{\mathrm{a}}$ & $<2.0 \pm 0.0^{\mathrm{b}}$ \\
\hline $\mathrm{E}$ & $4.7 \pm 0.9^{b}$ & $3.4 \pm 0.5^{b}$ & $3.6 \pm 0.8^{\mathrm{ab}}$ & $3.0 \pm 0.0^{\mathrm{b}}$ & $<2.0 \pm 0.0^{\mathrm{b}}$ & $<2.0 \pm 0.0^{\mathrm{a}}$ & $4.8 \pm 2.1^{\text {a }}$ & $3.7 \pm 0.8^{\mathrm{a}}$ & $3.5 \pm 0.7^{\mathrm{a}}$ \\
\hline $\mathrm{F}$ & $6.7 \pm 0.5^{\mathrm{a}}$ & $4.5 \pm 0.5^{\mathrm{ab}}$ & $4.4 \pm 0.5^{\mathrm{ab}}$ & $4.0 \pm 1.2^{\mathrm{ab}}$ & $<2.0 \pm 0.0^{\mathrm{b}}$ & $<2.0 \pm 0.0^{\mathrm{a}}$ & $6.1 \pm 0.4^{\mathrm{a}}$ & $3.2 \pm 0.3^{\mathrm{a}}$ & $<2.0 \pm 0.0^{\mathrm{b}}$ \\
\hline G & $6.5 \pm 0.4^{\mathrm{a}}$ & $5.1 \pm 1.5^{\mathrm{a}}$ & $5.0 \pm 1.7^{\mathrm{a}}$ & $3.0 \pm 0.0^{\mathrm{b}}$ & $<2.0 \pm 0.0^{\mathrm{b}}$ & $<2.0 \pm 0.0^{\mathrm{a}}$ & $5.6 \pm 1.0^{a}$ & $4.1 \pm 2.0^{\mathrm{a}}$ & $4.2 \pm 0.5^{\mathrm{a}}$ \\
\hline $\mathrm{H}$ & $6.7 \pm 0.4^{\mathrm{a}}$ & $4.5 \pm 0.4^{\mathrm{ab}}$ & $4.1 \pm 0.6^{\mathrm{ab}}$ & $3.7 \pm 0.9^{b}$ & $<2.0 \pm 0.0^{\mathrm{b}}$ & $<2.0 \pm 0.0^{\mathrm{a}}$ & $4.4 \pm 1.8^{\mathrm{a}}$ & $3.3 \pm 0.6^{a}$ & $3.1 \pm 0.2^{\mathrm{a}}$ \\
\hline
\end{tabular}

TVC, Total Viable Count; a,babvalues having a common letter are not significantly different at P-level=5\%. A lettering system was used to determine if there was any significant school-to-school difference within each product category. $<2$ Log CFU/g represents the limit of detection of the plating methodology. 
Kotzekidou (2013) recovered $S$. aureus from $11 \%$ of sandwiches with counts between 2-4 Log CFU/g (Kotzekidou, 2013). The Food and Drug Administration has established that effective doses of staphylococcal enterotoxins are usually elaborated when populations of $S$. aureus attain a population density of $>5 \mathrm{Log}$ $\mathrm{CFU} / \mathrm{g}$ at $\mathrm{pH}$ close to neutrality (Cornu and Rosset, 2004). Only faratas purchased at one out of eight schools was found to harbour $S$. aureus at a level enough to cause staphylococcal intoxication. Although this level was not exceeded in the other food items, the presence of $S$. aureus is suggestive of possible cross-contamination between the food handler and the food. The primary reservoir of $S$. aureus is the human nasal cavity with $30 \%$ of adults harbouring this organism permanently and 50\% intermittently (Wertheim et al., 2005). Indeed, Hatakka et al. (2000) and El-Scherbeeny et al. (1985) isolated $S$. aureus from the nose, throat, hands and nail samples of food handling personnel and further demonstrated the potential for the pathogen to spread from the nose to the skin, hands and the environment. Bankolé et al. (2012) indicated that one sneeze is enough to propel billions of microorganisms in the environment. Under favourable conditions of temperature and relative humidity and considering that 20 minutes is enough for one generation of bacterial cell division (Cornu and Rosset, 2004), bacteria can multiply to potentially hazardous levels within a short timeframe. Hence, it can be inferred that methods of food handling by vendors from preparation to sale can provide multiple routes of bacterial transference as well as potential for pathogen growth in the food sold. The population density of $E$. coli of the different food items ranged from 3.45.1, <2-3.9, and <2-4.1 Log CFU/g for faratas, panini, and fried noodles respectively. E. coli was undetectable (by plating) in panini in all schools except for one canteen where a mean population of $2.6 \mathrm{Log}$ $\mathrm{CFU} / \mathrm{g}$ was recorded. According to the New Zealand Food Regulations (1984), the maximum allowable level of $E$. coli in RTE foods is $2 \mathrm{Log} \mathrm{CFU} / \mathrm{g}$. This level was clearly exceeded in almost all faratas and fried noodles samples analyzed. The frequency with which $E$. coli, a member of the Enterobacteriaceae family, was isolated in this study $(67 \%)$ is higher than the level of enterobacteria observed by El-Scherbeeny et al. (1985) in street-vended foods in Egypt (Bankolé et al., 2012). E. coli could have likely originated from hands of workers, which is indicative of poor compliance with the code of hygienic practices (Mirabaud, 2003) and, like other coliforms, may increase due to thermal abuse. Dougnon et al. (2012) in fact conducted a survey and confirmed the role of feces as one of the main sources of microorganisms in food (Dougnon et al., 2002).

L. monocytogenes, Salmonella, and $C$. perfringens were undetected in all of the food samples during both sampling rounds. L. monocytogenes is a ubiquitous geophilic (environmental) pathogen often found on food processing equipment. Cross-contamination of RTE food by L. monocytogenes has in the past resulted in outbreaks of listeriosis and major product recalls in other countries (Lin et al., 2006). This is because listeriae can survive on processing equipment, such as meat slicers, which serve as a potential contamination source. Contrary to our findings, other studies have revealed that ingredients of sandwiches such as salad vegetables and sliced meat products harboured L. monocytogenes at varying frequencies (5-9\%), thus making sandwiches a high-risk food (Guerra et al., 2001). The absence Listeria spp. in the food items tested probably suggests that utensils and kitchenware were regularly cleaned and sanitized. Salmonella and C. perfringens rank among the top five most important foodborne pathogens in many countries (Scallan et al., 2011). Salmonella is mostly transmitted from animals to man through consumption of foods of animal origin and is thus classified as a zoonotic pathogen. Non-typhoidal salmonellosis (enteritis) is usually self-limiting but can occasionally engender complications such as bacteraemia. C. perfringens occurs naturally in the intestines of animals as well as in environmental niches such as soil and water; making it therefore a "zoonotic" and "geonotic" pathogen. Our findings indicated the absence of Salmonella and C. perfringens in chicken panini and curry-filled faratas although these pathogens have been previously isolated from chicken sandwiches and gravies respectively (Mason et al., 2001; Moore et al., 2003). This is in contrast with findings of Christison et al. (2008) who isolated Salmonella at a frequency of $17.5 \%$ from filled baguettes sold at retail delicatessens in South Africa and Bankolé et al. (2012) who observed the presence of sulphite-reducing clostridia in school canteen meals (Scallan et al., 2011).

It is worthwhile mentioning that these microbiological investigations were carried out in winter during the period of August to September 2014. Since foodborne infections are usually more widespread and frequent in summer (Doyle, 1984), it is anticipated that the microbiological status of these RTE items would be poorer during summer months (November-April) due to the higher prevailing temperatures. This is congruent with the official statistics of the Ministry of Health and Quality of Life (MoHQL, 2013), which have previously highlighted notification of more cases of food poisoning in the months of November and December affecting people of the young age group of 10-19 years old (i.e. secondary school students).

\section{Conclusions}

Canteen RTE food items, such as faratas, panini, and fried noodles are popular food commodities among Mauritian school children owing to their convenience, affordability, taste, and wholesomeness. Panini sampled from all schools were found to have a satisfactory microbiological and sanitary quality. However, microbiological analyses of faratas sampled from eight random secondary schools indicated the presence of moderately high levels of mesophilic aerobic bacteria, moderate levels of foodborne pathogen $S$. aureus and unacceptably high levels of fecal indicator E. coli when compared with published microbiological criteria used for RTE foods. Fried noodles purchased from the eight different canteens also often harboured objectionably high levels of $S$. aureus. This probably reflects the inadequate personal hygiene of canteen workers since the preparation of fried noodles and faratas involves extensive manual manipulation of the ingredients. The poor microbiological quality could also be attributed to the use of contaminated raw materials, cross-contamination during preparation, improper handling and/or conservation. Overall, the findings point out that general principles of good manufacturing practices and food hygiene as well as temperature control should be enforced. Maintenance of correct refrigeration is also fundamental for the safety of these foods and should not be underrated.

\section{References}

Abdussalam M, Käferstein FK, 1993. Safety of street foods. World Health Forum 14:191-4.

Bankolé HS, Dougnon TJ, Edorh PA, Dougnon TV, Legonou M, Klotoé JR, Loko F. Portage of bacteria responsible of foodborne illness in scholarly canteens (Republic of Benin). Adv Microbiol 2:340-44.

Bello M, Lawan MK, Kwaga JK, Raji MA, 2011. Assessment of carcass contamination with E. coli $\mathrm{O} 157$ before and after 
washing with water at abattoirs in Nigeria. Int J Food Microbiol 150:1846.

British Sandwich Association (BSA), 2007. So what is a sandwich? Available from: http://new.sandwich.org.uk/ Accessed: May 2015

CDC (Centers for Disease Control and Prevention), 2009. Preliminary FoodNet data on the incidence of infection with pathogens transmitted commonly through food. Morb Mortal Wkly Rep 58:333-7.

Christison CA, Lindsay D, von Holy A, 2008. Microbiological survey of readyto-eat foods and associated preparation surfaces in retail delicatessens, Johannesburg, South Africa. Food Control 19:727-33.

Cornu M, Rosset P, 2004. Appréciation quantitative de la croissance bactérienne potentielle à partir de profils temps-température - Exemples d'application pour la croissance de Salmonella Typhimurium dans un steak haché. Bull Acad Vét France 157:93-100.

Dougnon TV, Bankolé HS, Edorh AP, Dougnon JT, Gouissi M, Hounkpatin A, Montcho S, Azonhè H, Klotoé JR, Boko M, 2012. Evaluation of the microbiological quality of the leaves of Solanum macrocarpum L. cultivated with the chicken's droppings and water of marsh in Cotonou (Republic of Benin). Int $\mathrm{J}$ Biosci 2:45-52.

Doyle MP, 1984. Association of Campylobacter jejuni with laying hens and eggs. Appl Environ Microbiol 47:533-36.

Edema MO, Omemu AM, 2004. Microbiology and food hygiene in public food services. In Eromosele IC, Arowolo TA, Popoola TOS, Akpan IA, eds. Proceedings of the First International Conference on Science and National Development, 2004 Oct 25-28, Abeokuta, Nigeria, Federal University of Agriculture, pp 25-9.

El-Scherbeeny MR, Saddik MF, Bryan FL, 1985. Microbial profiles of food sold by street vendors in Egypt. Int $J$ Food Microbiol 2:355-64.

Fon MSTS, Goburdhun D, Neetoo H, 2016. A study on the microbiological quality of fresh noodles sold in Mauritius. Afr J Food Sci Technol 7:125-30.

Ghaffar S, Abdulamir AS, Abu Bakar F, Karim R, Saari N, 2009. Microbial growth, sensory characteristic and $\mathrm{pH}$ as potential spoilage indicators of
Chinese yellow wet noodles from commercial processing plants. Am J Appl Sci 6:1059-66.

Gillespie I, Little C, Mitchell R, 2000. Microbiological examination of cold ready-to-eat sliced meats from catering establishments in the United Kingdom. J Appl Microbiol 88:467-74.

Guerra MM, McLauchlin J, Bernardo FA, 2001. Listeria in ready-to-eat and unprocessed foods produced in Portugal. Food Microbiol 18:423-29.

Hatakka M, Björkroth KJ, Asplund K, Mäki-Petäys N, Korkeala HJ, 2000. Genotypes and enterotoxicity of Staphylococcus aureus isolated from the hands and nasal cavities of flightcatering employees. J Food Prot 63:1487-91

Hayes C, Elliot E, Krales E, Drowner G, 2003. Food and water safety for persons infected with human immunodeficiency virus. Clin Infect Dis 36:S106-9.

Hotee MF, 2011. A critical analysis of food poisoning in Mauritius. Masters Diss., University of Mauritius, Mauritius.

International Commission on Microbiological Specification for Foods (ICMSF), 1996. Microorganisms in Foods $5-$ Characteristics of Microbial Pathogens. 1st ed. Blackie Academic \& Professional, London, UK.

Kotzekidou P, 2013. Survey of Listeria monocytogenes, Salmonella spp. and Escherichia coli O157:H7 in raw ingredients and ready-to-eat products by commercial real-time PCR kits. Food Microbiol 35: 86-91.

Lin CM, Takeuchi K, Zhang L, Dohm CB, Meyer JD, Hall PA, Doyle MP, 2006. Cross-contamination between processing equipment and deli meats by Listeria monocytogenes. J Food Prot 69:71-9.

Lues JFR, Van Tonder I, 2007. The occurrence of indicator bacteria on hands and aprons of food handlers in the delicatessen sections of a retail group. Food Control 18: 326-32.

Mason BW, Williams N, Salmon RL, Lewis A, Price J, Johnston KM, Trott RM, 2001. Outbreak of Salmonella indiana associated with egg mayonnaise sandwiches at an acute NHS hospital. Commun Dis Public Health 4:300-4.

Meftahuddin T, 2002. Review of the trends and causes of food borne outbreaks in Malaysia from 1988 to 1997 . Med J Malaysia 57:70-9.

Mirabaud MI, 2003. Entérobactéries à béta- lactamases à spectre élargi en pédiatrie en 1996. PhD Diss., Université de Genève, Switzerland.

Ministry of Health and Quality of Life (MoHQL), 1999. The Food Act 1998 Regulations made by the Minister under Section 18 of the Food Act 1998. Government Notice No. 173 of 1999, p. 294. Government Notice, Mauritius.

Ministry of Health and Quality of Life (MoHQL), 2014. Health Statistics Report 2014, Island of Mauritius and Island of Rodrigues. Available from: http://health.govmu.org/English/Statisti cs/Health/Mauritius/Documents/annual\%20report\%202014.pdf Accessed: July 2016

Moore CM, Sheldon BW, Jaykus LA, 2003. Transfer of Salmonella and Campylobacter from stainless steel to romaine lettuce. J Food Prot 66:2231-6.

New Zealand Food Regulations (NZFR), 1984. The Food Regulations 1984. Available from: http://www.nzlii.org/nz/legis/num_reg/f r1984166/ Accessed: July 2016.

Pinto M, Burri S, Mena C, Almeida G, Carneiro L, Teixeira P, Gibbs PA, 2001. Comparison of Oxford Agar, PALCAM and Listeria monocytogenes Blood Agar for the recovery of L. monocytogenes from foods and environmental samples. Food Control 12:511-514.

Scallan E, Hoekstra RM, Angulo FJ, Tauxe RV, Hoekstra RM, 2011. Foodborne illness acquired in the United States Major pathogens. Emerg Infect Dis 17:7-15.

Scharff RL, McDowell J, Medeiros L, 2009. Economic cost of foodborne illness in Ohio. J Food Prot 72:128-36.

Soon JM, Singh H, Baines R, 2011. Foodborne diseases in Malaysia: A review. Food Control 22:823-30.

Soriano JM, Blesa J, Rico H, Moltó JC, Mañes J, 2002. Incidence of Staphylococcus aureus in meals from cafeterias. J Food Saf 22:135-40.

Tomohide Y, 2010. Food safety regulation in the United States - an empirical and theoretical examination. The Independent Review 15: 201-26.

Wertheim HFL, Melles DC, Vos MC, van Leeuwen W, van Belkum A, Verbrugh HA, Nouwen JL, 2005. The role of nasal carriage in Staphylococcus aureus infections. Lancet Infect Dis 5:751-62. 